\title{
Capital Structure Determinants in Property and Real Estate Company in 2013 to 2018
}

\author{
Sautma Ronni Basana ${ }^{1 *}$, Tiffany Tandarto ${ }^{1}$, and Christina Soehono ${ }^{2}$ \\ ${ }^{1}$ Management Department, Faculty of Business and Economics, Petra Christian University, \\ Jl. Siwalankerto 121-131, Surabaya 60236, Indonesia \\ ${ }^{2}$ Chung Yuan Christian University, Taiwan, No. 200, Zhongbei Road, Zhongli District, \\ Taoyuan City, Taiwan 320
}

\begin{abstract}
This research is to recognize the factors supporting the property and real estate company in determining the capital structure composition. The population of this research is all the property and real estate company listed on the Indonesia Stock Exchange 2013 to 2018. There are 48 companies listed until 2019. The data analysis employs a stratum test. The results of this research are the company's performance, profitability influencing the capital structure, growth that does not influence the capital structure, nondebt tax shield influencing capital structure, and liquidity does not influence capital structure. In the company's risk, the collateral value of assets influences capital structure; on the other hand, the business risk does not influence the capital structure. In the company's characteristics, company size does not influence the capital structure.
\end{abstract}

Keywords: Capital, characteristic, financing, performance, risk, structure.

\section{Introduction}

Indonesia has the largest population, ranked fourth after the United States, but it is undeniable that the equal distribution of boarding access is not realized yet. According to the Indonesian Stock Exchange, a company that the business engages in the existing property is categorized in the real estate and property sector. The real estate industry is a property company engaging in providing procurement and land maturing for industrial businesses, including the tourism industry. Tight competition is seen from each property and real estate agency; according to the Indonesian Stock Exchange, in 2007, there are 38 companies in the property and real estate, and it grows to 48 listed companies in 2018.

The company's financing source is split into two, internal and external sources. Internal financing source comes from saved profits and owner's capital deposits. External financing source comes from investors, creditors, and company owners. The characteristics of the companies are measured by their sizes. The big company is easy to get financing from the lender because it is operational activity is running stable.

\footnotetext{
*Corresponding author: sautma@petra.ac.id
} 
The property and real estate industry in 2018 has a Debt to Asset Ratio (DAR) trend increasing from 2013 to 2018. As seen in Figure 1, about DAR levels of the property and real estate company.

\section{Debt to Asset Ratio (\%)}

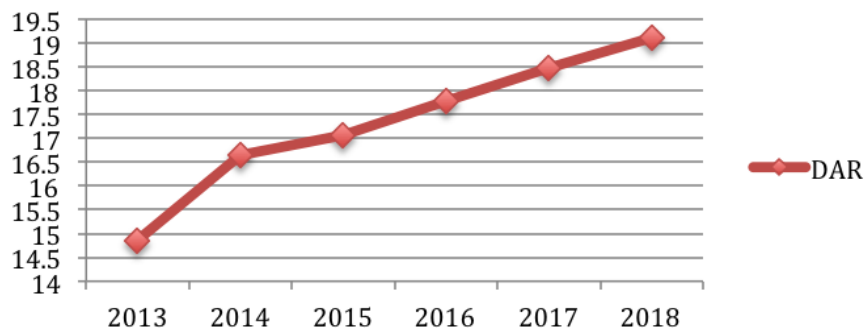

Fig. 1. Debt to asset ratio

Choosing the right financing influences the company's operational activity so it needs to be studied what factors supporting property and real estate companies in determining the capital structure composition.

\section{Supporting theory}

\subsection{Capital structure theory}

Pecking order theory is an internal financing source order (saved profits) and external (new equity issuance). Pecking order theory states that companies prefer internal financing than external financing. But if the external financing is needed, the company will issue the most secure securities, such as bonds, and issuing stocks is the last step [1].

Trade-Off Theory is about the relationship between capital structure and the company value. The trade-off model assumes that the company capital structure is a result of a tradeoff from the benefits of tax by using debt with the cost that will arise as a consequence of using debt. It means that it balances the benefits and sacrifices as a consequence of using debt [2].

\subsection{Capital structure}

Capital Structure is balancing or comparing the long term debts with the capital or equity [3]. Capital structure is long term permanent financing consolidation (proportion) of a company pointed by debt, preference stock equity and common stock [4]. The capital structure is the proportion between debt spending and owner's equity in a company's financial structure.

\subsection{Company performance}

The company's performance shows the company's ability to produce profits or returns of the investment resources. Returns of capital investment are an important indicator of a company's long term power [5].

Profitability is a company's ability to produce profits in relation to the selling, total assets, or owner's equity. Profitability is measured by ROA (Return of Investment) that is earning before tax divided by total assets. This formula is used because ROA is easy to be 
understood. It is a measuring tool of management achievement which is sensitive to each influence of the company's financial situation. This is needed because this research is related to the capital structure with the company's financing. The formula is as follow :

$$
\text { ROA = Net Income / Average Assets }
$$

The changes are seen from the increasing of the company's assets periodically [6]. If the growth is increasing high, the company's value is better for the investors. The growth is measured by the following formula :

$$
\text { Asset Growth }=\left(\text { Total Asset }_{\mathrm{t}}-\text { Total Asset }_{\mathrm{t}-1}\right) / \text { Total Asset }_{\mathrm{t}-1}
$$

Non Debt Tax Shield is tax benefits a company received except debts. It is a tax deduction in fixed assets depreciation of a company [7]. Depreciation and amortization is the company's cash-flow, because if the depreciation and amortization are higher, it can be used as capital to reduce the company's tax.

Liquidity shows the ability of a company to fulfill the short term obligation, such as paying off the short term of due date debt [8]. The higher this ratio, the higher the company's affordability in paying off the debt.

\subsection{Company's risk}

The company's risk is the risk that arises because of the uncertainty of the future in running the company, for example, unsold and worn products, risk of mistake in the company's accounting system, stock price fluctuations, etc [9]. The collateral value of the asset is the balancing of fixed assets and total assets [10]. Business risk is a risk faced by the company when running the operation of a company [11].

\subsection{The characteristics of the company}

The characteristics of company are some inherent things to a company so that the company is recognizable by those things.

The company's size is measured by the value of the equity, the selling value, and the assets. A big company usually easily gets external funding. Besides, a big company has high bargaining power and has a big opportunity in winning the competition or surviving in the industry [12].

\subsection{The relation between concepts}

In this research, the company's performance is measured by the profitability ratio, company's growth, non debt tax shield and liquidity.

The company's profitability influences its capital structure. If the company has high profitability, the company will use debt lower or the other way around. It is able to reduce the capital structure, in the form of debt. This statement is in line with the pecking order theory, which states that manager in taking financing decision is likely to use internal financing first (saved profits) instead of external financing (debt). It is supported that the profitability is influenced by the capital structure [13, 14]. Seftianne and Handayani [15] that state that profitability is not influenced the capital structure.

A company that has high growth is reflected through the high profitability. It makes the outsiders especially lenders to trust the company, and it is easy for the company to lend 
money. The high growth company in organizing the capital structure tends to use external financing. The company's growth influences significantly toward capital structure [15].

A company that has non debt tax shield usually has low debt level. The reason is that the depreciation load can be used as substitution of tax field that comes from the interest of debt load, so that the company does not need to use a lot of debts as the debt shield. Non debt tax shield does not influence toward capital structure [16], but according to Ozkan [17] non debt tax shield significantly influences the capital structure.

The high level of liquidity of a company shows that the company produces cash flow to fulfill the activity with the current assets. However, if it is too high, it will have an adverse impact on the company's ability, because some of the unproductive fund is invested in current assets, so the profitability is not optimal. Liquidity influences significantly toward capital structure $[17,18]$. Liquidity does not influence significantly toward capital structure [15].

In this research, the risk of a company is measured by the ratio of collateral value of assets and business risk. If a company has bigger long term fixed assets, it will use more long term debts, because it is hoped that the assets can be used to cover the long term debts. It can be said that collateral value of assets can be used to determine how big the long term debt that can be taken and this will influence the determination of how big the capital structure of a company [19].

Business risk is the uncertainty faced by a company in running its business activity [10]. If the business risk increases, the capital structure will decrease, because the company that has high business risk in using its debt will increase the risk of bankruptcy. But if the company has low business risk, it means that it has optimal debt risk [20]. Business risk influences significantly toward capital structure [11]. Business risk does not influence significantly toward capital structure [15].

In this research, the characteristics of a company is measured by the company's measuring ratio. The bigger a company size, the easier it is to get lending from a third party. The size influences the investor's trust. The size of a company influences significantly toward capital structure [19]. The size of a company does not influence significantly toward capital structure [21].

\subsection{Research framework}

Hypothesis:

1: Company's performance significantly influences toward capital structure

1.1: Profitability significantly influences toward capital structure.

1.2: Company's growth significantly influences toward capital structure.

1.3: Non debt tax shield significantly influences toward capital structure

1.4: Liquidity significantly influences toward capital structure.

2: Company's risk significantly influences toward capital structure

2.1: Collateral value of asset significantly influences toward capital structure.

2.2: Business risk significantly influences toward capital structure.

3: Company's characteristic significantly influences toward capital structure

3.1: Company's size significantly influences toward capital structure 


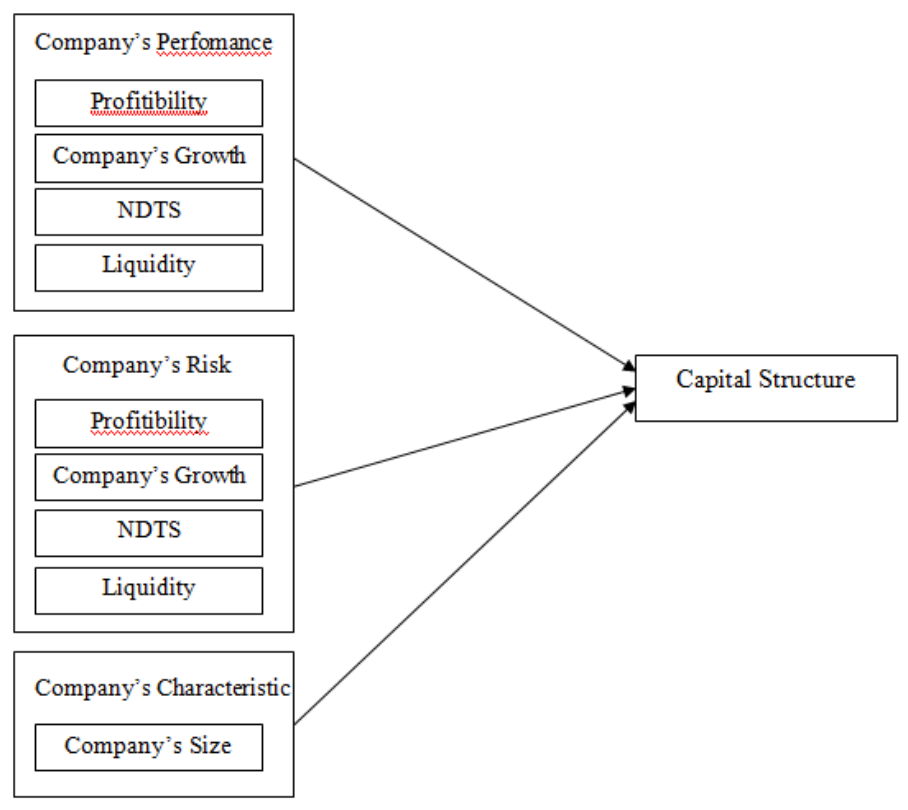

Fig. 2. Research framework

\section{Research method}

The type of this research uses associative research. This research examines the performance, risk, and characteristic toward capital structure of property and real estate companies listed on Indonesia Stock Exchange 2013 to 2018. The population of this research is all the property and real estate companies listed on Indonesia Stock Exchange 2013 to 2018. The sampling uses purposive sampling method with the following criteria: (i)Listed on Indonesia Stock Exchange 2013 to 2018 ; (ii) Releasing its financial report every year ; (iii) The variable data (profitability, company's growth, NDTS, liquidity, CVA, business risk and company's size) must have a positive value because it will be transformed into ln (natural logarithm).

The type of data in this research uses secondary data, and the data source is received from the financial and annual reports from Bloomberg. The data collection method used in this research is documentary technique. This technique is a data collection method by searching and collecting data of financial reports listed on Indonesia Stock Exchange 2013 to 2018. The data can be accessed on Bloomberg (www.bloomberg.com)

The Classic Assumption Testing used in this research is covering multicollinearity, autocorrelation, and heteroscedasticity testing. Multicollinearity testing used to see the correlation between independent variable in regression model. It can be seen that there is no multicollinearity in each tested variable. It is because VIF is not more than 10. It can be concluded that in this research, there is no multicollinearity.

Autocorrelation arises if there is a correlation between data in space (cross-section) or time (time series). Based on Table 2, it can be seen that the autocorrelation on the regression equation. 
Table 1. Multicollinearity testing

\begin{tabular}{|c|c|c|}
\hline Variables & VIF & Result \\
\hline PROFITABILITY & 2.77 & No Multicollinearity \\
\hline GROWTH & 1.17 & No Multicollinearity \\
\hline NDTS & 1.20 & No Multicollinearity \\
\hline LIQUIDITY & 1.25 & No Multicollinearity \\
\hline CVA & 1.39 & No Multicollinearity \\
\hline BR & 2.87 & No Multicollinearity \\
\hline SIZE & 1.17 & No Multicollinearity \\
\hline
\end{tabular}

Table 2. Autocorrelation Testing

\begin{tabular}{|c|c|}
\hline Prob F & Result \\
\hline 0.0000 & Autocorrelation \\
\hline
\end{tabular}

Heteroscedasticity testing is used to see if regression model has variant inequality from residual between observations. Based on Table 3. it can be seen that there is heteroscedasticity in regression equation. To resolve this, it can use regression with the existence vce (cluster) to make it robust toward heteroscedasticity and autocorrelation.

Table 3. Heteroscedasticity Testing

\begin{tabular}{|c|c|}
\hline Prob F & Result \\
\hline 0.0000 & Heteroscedasticity \\
\hline
\end{tabular}

Determination Coefficient $\left(\mathrm{R}^{2}\right)$ is used to measure the ability of independent variable in explaining the dependent variable.

Table 4. Determination Coefficient Testing

\begin{tabular}{|c|c|}
\hline Adjusted R-Square & $19.34 \%$ \\
\hline
\end{tabular}

Based on Table 4, it can be seen that the coefficient determination (Adjusted R-Square) is $19.34 \%$. This means that the dependent variable can only be explained about $19.34 \%$ by the independent variable, while the rest is explained by the other variable that is not explained in this research.

Coefficient regression test (t-test) has purpose to show how big the influence of an independent variable toward dependent variable. From Table 5, it can be seen that after repeated significance variable regression with the $10 \%$ significance level, the significant variables are profitability variable, the collateral value of asset (CVA), and non debt tax shield (NDTS). On the other hand, variable size, risk (BR), growth, and liquidity are insignificant.

Table 5. Partial Test (t-test)

\begin{tabular}{|c|c|c|c|}
\hline Variables & Coefficient & Prob. & Result \\
\hline C & -0.437 & 0.517 & Insignificant \\
\hline PROFITABILITY & 1.172 & 0.068 & Significant \\
\hline GROWTH & -0.071 & 0.256 & Insignificant \\
\hline NDTS & -7.475 & 0.090 & Significant \\
\hline LIQUIDITY & 0.009 & 0.643 & Insignificant \\
\hline CVA & 0.014 & 0.002 & Significant \\
\hline BR & -2.179 & 0.436 & Insignificant \\
\hline SIZE & 0.052 & 0.330 & Insignificant \\
\hline
\end{tabular}




\section{Discussion}

The performance of a company can be measured by the profitability, company's growth, non debt tax shield, and liquidity. The results of the Company's performance are as follows: (i) Profitability toward Capital Structure, (ii) Company's Growth toward Capital Structure, (iii) Non-Debt Tax Shield toward Capital Structure, and (iv) Liquidity toward Capital Structure.

The result of regression analysis is found that profitability influences the capital structure of property and real estate companies. In the business, property companies use pre-order wherein a certain period, the company will promote its project to attract customers. This will not make the company depends on debt financing source or equity [22]. Besides that, in their effort, property and real estate companies need land to build their product, where low prices land is hunted by the developers. The company needs big capital to build by using additional capital outside the internal fund [15].

The result of this research shows that the company's growth does not influence toward capital structure of property and real estate companies. There is no influence on selling growth toward the capital structure. It explains that the size of the selling in a period will not influence the increase in a company's debt. This is because the companies of this research have growth with an average value of $16.07 \%$. Because of the relatively small growth, it needs smaller capital, as a result, the financing can be used from available equity.

The result of this research shows that non debt tax shield influences toward capital structure of property and real estate companies. This shows that the bigger the non debt tax shield or the efficiency of the tax in the form of depreciation of fixed assets, the bigger the capital structure that comes from the use of the company's debt. This is supported by the Trade-off Theory that more debts will protect in the form of debt interest expense that can reduce tax. Besides, depreciation as an encouragement for the company to reduce its debt because depreciation is cash flow as a capital source that can reduce the financing from debt.

The result of the test in this research shows that liquidity variable does not influence toward capital structure variable of property and real estate companies. This is because the company will reduce the use of long term debt along with the increasing of the company's liquidity. The high liquidity shows that internal financing is enough to pay the debt. Therefore the capital structure will decrease. By seeing the selling system of property and real estate companies that use the pre-order system, the companies will have enough money to finance its operational cost $[17,18]$.

In this research, the risk of the company is measured by the collateral value of assets and business risk. The result of the business risk testing in this research is as follows (i) collateral value of asset toward capital structure and (ii) business risk.

The result shows that the collateral value of asset influences toward capital structure of property and real estate companies. The company that has big fixed assets shows that it has a high asset structure; it is because of the big scale of the company is easy to access the financing source compared to a small company [19, 23].

Based on the result of the testing of the business risk variable toward capital structure, it shows that the business risk variable does not influence capital structure. This indicates that it is uncertain if the company with high-risk choosing to use internal financing compared to use external debt. It is the other way around; the low-risk business company is uncertain about choosing external financing to invest or develop its business.

The characteristic of a company can be its size. The result shows that the company's size does not influence the capital structure of the property and real estate companies. This is because in every use of financial source both internal and external, it has different capital and different levels of risks. Every company, big or small, must use the most secure one first that is the internal source, rather than an external source. Besides, if the economy is 
unstable, the company will determine how to manage the capital structure by its policies [21].

\section{Conclusion}

It can be concluded that in company's performance variable, the profitability influences toward capital structure, company's growth, and liquidity does not influence toward capital structure, non debt tax shield influences toward capital structure; company's risk variable, the collateral value of asset influences toward capital structure, but the business risk does not influence capital structure; company's characteristic variable, which is the size, does not influence the capital structure. In this research, there are some suggestions that are mentioned: (i) The management of the companies should pay attention to variables influencing their capital structure before setting the policy of their capital structure. (ii) The next research should widen the object of research, not only in property and real estate, but the object can be added, such as manufacturing companies.

\section{References}

1. V. Bhama, P. Jain, S. Yadav, International Journal of Managerial Finance, 12,3, 335350(2016). https://doi.org/10.1108/IJMF-06-2014-0095

2. N.A. Sheikh, Z. Wang, Managerial Finance, 37,2:117-133(2011). https://doi.org/10.1108/03074351111103668

3. J. Burgstaller, E. Wagner, Journal of Risk Finance, 16,1:73-101(2015). https://doi.org/10.1108/JRF-06-2014-0091

4. V. Horne, Jr. Wachowicz, Fundamentals of Financial Management, England: Prentice Hall (2007). http://www.academia.edu/download/46965249/Financial_Management_by_Van_Hor $\underline{\text { n.pdf }}$

5. R. Jordão, V. Almeida, Journal of Intellectual Capital, 18,3:643-666(2017). https://doi.org/10.1108/JIC-11-2016-0115

6. D. Setiawan, Jurnal Ekonomi dan Bisnis Indonesia, 19,3:224-237(2005) [in Bahasa Indonesia]. http://i-lib.ugm.ac.id/jurnal/detail.php?dataId=10242

7. J.A. Clemente-Almendros, F. Sagorb-Mira, Revista de Contabilidad 21,2:162175(2018). https://doi.org/10.1016/j.rcsar.2018.05.001

8. D. Astuti, Manajemen Keuangan Perusahaan. [Corporate Financial Management.]. Jakarta: Ghalia Indonesia (2004). [in Bahasa Indonesia]. http://repository.usu.ac.id/bitstream/handle/123456789/41939/Reference.pdf?sequenc $\mathrm{e}=2$ \&isAllowed $=\mathrm{y}$

9. E.S. Mokhtar, H. Mellett, Managerial Auditing Journal, 28,9:838-865(2013). https://doi.org/10.1108/MAJ-11-2012-0776

10. E.F. Brigham, J.F. Houston, Essentilas of Financial Management, Singapore: Thomsom Learning (2007). https://www.worldcat.org/title/essentials-of-financialmanagement/oclc/853603323

11. A.N. Primantara, M.R. Dewi, E-Jurnal Manajemen Unud. 5,5:2696-2726(2016). [in Bahasa Indonesia]. https://ojs.unud.ac.id/index.php/Manajemen/article/view/20553

12. S.P. Lisa, C.Y. Jogi, Journal Business Accounting Review, 1(2),298-305(2013). [in Bahasa Indonesia]. http://publication.petra.ac.id/index.php/akuntansibisnis/article/view/1050

13. H. Nurrohim, Jurnal Bisnis dan Manajemen, 10,1:11-18(2008) [in Bahasa Indonesia]. https://journal.uii.ac.id/Sinergi/article/view/873

14. Antoni, C. Chandra, F. Susanti, Jurnal Benefita, 1,2:78-94(2016). [in Bahasa Indonesia]. http://doi.org/10.22216/jbe.v1i2.1429 
15. Seftianne, R. Handayani, Jurnal Bisnis dan Akuntansi, 13,1:39-56(2011). [in Bahasa Indonesia]. https://doi.org/10.34208/jba.v13i1.214

16. S.N. Bhaduri, Journal of Economics and Finance, 26,2:200-215 (2002). https://link.springer.com/article/10.1007/BF02755986

17. A. Ozkan, Journal of Business Finance and Accounting, 28,1-2:175-198(2001). https://onlinelibrary.wiley.com/doi/abs/10.1111/1468-5957.00370

18. Mutamimah. Jurnal Bisnis Strategi, 11,8:71-82(2017). [in Bahasa Indonesia]. https://ejournal.undip.ac.id/index.php/jbs/article/view/14153

19. A.B. Putri, Diponegoro Business Review, 1,1:1-11(2012). [in Bahasa Indonesia]. http://eprints.undip.ac.id/35842/

20. Budianto, S. Puspida, Jurnal Ilmu dan Riset Management, 2,2:1-15(2013). [in Bahasa Indonesia]. $\quad$ https://studylibid.com/doc/770125/pengaruh-risiko-bisnis-danpertumbuhan-aktiva-terhadap-st.

21. P.D. Putra, R. Thohiri, Jurnal Bina Akuntansi, 18,1:28-39(2013). [in Bahasa Indonesia].

https://scholar.google.co.id/scholar?hl=id\&as_sdt=0,5\&cluster $=741417391583978579$ $\underline{4}$

22. G.L. Oktaviani, M.I. Malelak, Finesta 2,2:12-16(2014). [in Bahasa Indonesia]. http://publication.petra.ac.id/index.php/manajemen-keuangan/article/view/2389

23. A. Denziana, E.D. Yunggo, Jurnal Akutansi dan Keuangan, 8,1:51-67(2017). [in Bahasa Indonesia]. http://jurnal.ubl.ac.id/index.php/jak/article/view/825/0 